\title{
The Comparison of Different Honey Bee Genotypes by Some Biochemical Parameters (Total Protein, Total RNA, Catalase and Malondialdehyde)
}

\begin{abstract}
Adnan Ünalan ${ }^{1, a, *}$, Ethem Akyol ${ }^{2, b}$
${ }^{1}$ Department of Biostatistics and Medical Informatics, Faculty of Medicine, Niğde Ömer Halisdemir University, 51240 Niğde, Turkey ${ }^{2}$ Department of Animal Sciences and Technologies, Faculty of Agricultural Siences and Technologies, Niğde Ömer Halisdemir University, 51240 Niğde, Türkiye

*Corresponding author

A R T I C L I N F O A B S T R A C T

Research Article

In this study, some biochemical characteristics (total protein, total RNA, Catalase: CAT enzyme activity and malondialdehyde: MDA level) of Italian bee (A. m. ligustica) and Caucasian bee (A. $m$. caucasica), and Muğla and Anatolian bees (A. m. anatolica) from local honey bee races were investigated comparatively. Laboratory analyzes of biochemical characteristics were performed on worker bees aged 24 days old with 10 repetitions using appropriate methods informed in the literature. The amounts of total protein of bee races given above were $18.39 \pm 1.28,20.71 \pm 0.63$, $18.56 \pm 1.24$ and $20.95 \pm 2.15 \mathrm{~g} / \mathrm{dL}$, respectively; the amounts of total RNA were $11.46 \pm 0.18$, $12.10 \pm 0.26,11.87 \pm 0.20$ and $12.27 \pm 0.26 \mu \mathrm{g} / \mu \mathrm{L}$, respectively; the CAT activities were $4.59 \pm 0.46$, $5.12 \pm 0.67,4.88 \pm 0.48$ and $5.25 \pm 0.53 \mathrm{kU} / \mathrm{g} \mathrm{P}$, respectively; the levels of MDA were $0.52 \pm 0.04$, $0.50 \pm 0.04,0.48 \pm 0.02$ ve $0.43 \pm 0.05 \mathrm{mmol} / \mathrm{mg}$, respectively. Variance analysis showed that statistically significant differences among races in terms of the all characteristics examined. The results of CAT activity which is one of the indicators of antioxidant defense system, and levels of MDA which is an indicator of peroxidation of membrane lipids; and similarly total amount of protein also includes various proteins such as antioxidants and enzymes; it can be said that the Anatolian and Caucasian bee races (due to higher total protein, total RNA and CAT activities, and lower MDA level) are more resistant to various negative environmental factors (e.g. climate, flora, pesticide, etc.) than the Muğla and Italian bee races in the conditions of the Central Anatolia Region; there are significant differences between the bee races in terms of amounts of total RNA and this parameter can be also used in the characterization of bee races.

Honey bee

Total protein

Total RNA

Catalase (CAT),

Malondialdehyde (MDA)
\end{abstract}

|b@eakyol@ohu.edu.tr (iD) https://orcid.org/0000-0001-8670-2625

\section{Introduction}

The honey bee, which spreads almost from the equator to the poles on the world, is considered to be a domestic animal, but it is found in the form of wild forms especially in the passage regions and in some places as different species. The different forms of the domestic honey bee, which has adapted perfectly to the climatic conditions, have been formed as a result of natural selection. The types of honey bee formed as a result of natural selection within a certain species are called race. Races were formed not in line with the economic needs of the producers of the region, but with the compelling effect of factors such as climate, flora and pests that constitute natural selection. The selection applied by beekeepers for the use of beneficial traits has changed the genotypes of natural races known through swarms that escape from colonies of different bee lineages. As a result, great variations have occurred even within a single race. Scientists use honey bees as race criteria; it uses the proportions of body parts, antenna lengths and morphometric measurements of some characters such as mouth parts and wing veins. Beekeepers, on the other hand, take into account behavioral characteristics such as good disposition, high honey production and tendency to son. The most important features determining the morphological differences in honey bee races; body size, body color, breast and abdominal rings width, tongue length, feather cover and wing veins. Features such as the number of hooks on the wing, the width of the metatarsus, the shape and size of the wax glands and the shape of the chitin plate of the male organ are also discussed. 
Honey bees (Apis mellifera L.) have adapted to many different ecological conditions in their natural range covering Europe, Africa and Asia. A large number of subspecies and ecotypes of honey bees that differ in morphology, physiology, behavior and genetics have been identified within such wide natural distribution areas. While some subspecies survive in large areas, some subspecies and all ecotypes spread in relatively smaller geographic areas and with smaller populations (Ruttner, 1988; Sheppard et al., 1997; Sheppard and Meixner, 2003; Strange et al., 2008; Silici and Özkök, 2009; Bouga et al., 2011). Along with these races and ecotypes, it is known that there are local honey bee populations that have adapted to the ecological conditions of their regions in terms of some characteristics (Ruttner, 1988; Genç et al., 1999). Turkey has very different climatic conditions, geological structure showing great differences from region to region, which is a genetic center for honey bee because of its natural bridge between Africa, Europe and Asia.

A. m. caucasica (Caucasian bee) in northeast of Turkey, A. m. meda (Persian bee) in southeast of Turkey and A.m. syriaca (Syrian bee) in Thrace region of Turkey, A. m. carnica (Carniolan bee) and A.m. Anatoliaca (Anatolian bee) subspecies in the remaining areas of Turkey are distributed (Ruttner, 1988; Kandemir and Kence, 1995; Smith et al., 1997; Güler, 1999; Güler and Kaftanoğlu, 1999; Kandemir et al., 2000; Palmer et al., 2000; Güler et al, 2011). With superior properties in terms of honey production in their natural area of expansion for which they Anatolian and the Caucasian honey bee races are used most frequently in the race to manufacture commercial breeding queens in Turkey due to these features. The Caucasian bee, which is the natural bee of Northeastern Anatolia, is known for its docile behavior and high honey yield characteristics, and it is grown intensively in many parts of the world, especially in high altitude regions (Genç et al., 2007; Güler, 2006; Güler, 2010). Anatolia has the widest span physiological honey bees in Turkey, a large number of different in terms of behavior and morphological characteristics and the local population has ecotypes (Bouge et al., 2011). According to the results obtained from various studies by Kekeçoğlu (2009) and Keçekoğlu and Soysal (2010), it was determined that the Caucasian group showed lower vitality characteristics than the Anatolian $(\mathrm{P}<0.01)$ and Yığılca $(\mathrm{P}<0.05)$ groups. The genetic differences between honey bee populations in Turkey is an important advantage for the development of the country's beekeeping (Akyol et al., 2005; Akyol et al., 2006). Honey bee races and ecotypes in Turkey have adapted to different ecological conditions (Rutter, 1988; Smith et al., 1997; Palmer et al., 2000). Anatolian and the Caucasian honey bee races and their reciprocal hybrids constitute a large portion of honey bee populations in Turkey. Anatolian bee has a large number of local populations, among which are Muğla bee, Yığılca bee and Giresun bee. However, the behavioral, physiological and productivity characteristics of many of these populations, which have not yet been protected in their natural areas, are not fully known (Bouga et al., 2011).

Turkey is one of the important gene center of the world beekeeping, in which bee population shows a wide variation in terms of various properties that have been adapted to different ecological conditions. This genetic variation and mutual interactions in Anatolian bee populations are increasing. The structural characteristics of the current population, the behavior patterns and yield levels in various regions, and the direction and dimensions of the change that migratory beekeeping and some other factors have caused on this population over time are not fully known. For this reason, it is important to identify the existing genotypes and determine the yield characteristics and behavior patterns in different ecological conditions. The studies done and to be done in this direction are also valuable in terms of both contributing to the breeding and selection studies on these races and being a guide for which honey bee race will give better results in which region or conditions. Because the amount of products such as honey and pollen produced in beekeeping, which is an agricultural activity dependent on nature, depends on the ecological conditions of the region, and the viability and reproductive abilities of honey bees are directly related to the environmental conditions they are in.

Apis mellifera differ in morphology and genetic characters. Examination of enzyme and mitochondrial DNA (mtDNA) differences are very useful methods to show genetic and geographic differences in honey bees. MtDNA differences reveal 4 bee lineages (western Europe, Eastern Europe, Africa and the newly announced Middle East pedigree). mtDNA studies in Turkey shows that of the Anatolian and Caucasian bees Eastern Europe. Although a lot to learn in terms of genetic differences in bees in Turkey these differences beekeeping stroller for various reasons, a small number and the same to each region using queens from the same origin bee races or ecotype is a serious danger that issues such as lost. Turkey is geographically in Europe, Asia and the Middle East and within the boundaries of the junction has a wide range of climates and regions. This situation creates an ideal location for biogeographical studies. That's why honeybees in Turkey, as expected, external appearance, behavior, show significant differences in terms of ecology and resistance to disease. Enzyme and mtDNA analyzes have revealed similarities with morphological results as well as new information. Rutter (1988) proposed 4 bee races in Turkey (Anatolian, Caucasian, Iran and Syria bee). He reported that Caucasian bees were in Northeast Anatolia and Eastern Black Sea coast, Iran bees were in Southeastern of Turkey, Sryia bees were in Southeastern of Turkey and Syrian border Anatolian bees were in remaining parts of Turkey and Thrace region. These genetic differences are the raw materials for solving problems in beekeeping, for example developing disease-resistant bee lines. If these different bee races are lost, there will be no raw material to be processed. Genetic diversity of honey bees in Turkey has begun to be studied later and DNA studies will allow us to reach more detailed information. These genetic differences are very important economically. Because each region's own bees are those that have adapted to the ecological conditions of that region and know how to survive in their region. New transportation vehicles and mobile beekeeping have caused diseases such as Varroa to be transmitted very quickly and the bees of different regions are difficult to adapt to the climate in the new region, and it is very difficult to combat diseases and bee pests in the new region. Today, without determining the loss of genetic diversity of Turkey bees are at risk. In addition, honey bees constitute the most important insect species affected by 
pesticides both in our country and in the world, and thousands of hives are damaged every year as a result of intensive and unconscious use of pesticides.

The probability of honey bees to be exposed to pesticides; it can be summarized as direct contact with the pesticide during the spraying during the flowering period of the plants, the drift of the drug droplets to the untargeted cultivated plants (during the flowering period) or water sources, the contact with the pesticide residues in the plant layers and the flower, and the transport of the pesticide contaminated nectar and pollen to the hive. The most typical signs of poisoning in honey bees are dead bees seen in front of the hive. The toxicity of drugs to bees is classified according to the 24-hour contact or oral LD50 values determined by the international bee-plant commission. Smart and Stephenson (1982) emphasized that the classification made based on the results obtained only in the laboratory could not always be applied to the field, and it was also important that the dose of the drug the bee would be exposed to in nature. Within the framework of this view, the number of lethal doses per unit area is found and the risk index is obtained by comparing the application dose of the drugs with the LD50 values determined in 24 hours in the laboratory.

As explained above, considering that various factors such as climate, flora and pesticides play a role in the formation of bee race and ecotypes, in this study, it was aimed to determine and compare some biochemical charecteristics (total protein, total RNA, catalase: CAT enzyme activity and malondialdehyde: MDA levels) of four different honey bee races which are widely used our country.

\section{Material and Method}

\section{Material}

Italian (Apis mellifera ligustica) and Caucasian (Apis mellifera caucasica) and Anatolian (Apis mellifera anatolica) and Muğla bee races (10 colonies in total, 3, 3, 2 and 2 colonies, respectively) used in the study were provided from beekeepers in Adana province. The purchased bee colonies were preserved in the Beekeeping Unit of Niğde Ömer Halisdemir University, Faculty of Agricultural Sciences and Technologies, Animal Production and Technologies Department.

\section{Method}

For the purpose of analyzing biochemical characteristics, 24 days old worker bees (approximately 100 -130 bees) from each race were collected as stock culture in May 2016 and kept in deep freezer at $-80{ }^{\circ} \mathrm{C}$ until biochemical analysis.

\section{Biochemical Analysis}

$1 \mathrm{~g}$ of worker (10-13 bees) bee from each bee race were weighed and homogenized (in $100 \mathrm{~mL} 2 \mathrm{mmol}$ phosphate buffer at $\mathrm{pH} 7.4$ ), then the homogenized samples were sonicated for 1.5 minutes and the sonicated samples were centrifuged for 15 minutes at $12,000 \times \mathrm{g}$. This sample preparation process to be used in biochemical analysis was repeated 10 times for each race. These supernatants prepared for each bee race were kept in the deep freezer at $-80^{\circ} \mathrm{C}$ until analyzed.

\section{Determination of Total Protein}

$1 \mathrm{~mL}$ of supernatant was used for analysis of the total protein. Total protein was evaluated by colorimetric test using standard bovine serum albumin according to the method reported by Lowry et al. (1951). This process was repeated 10 times for each bee race.

\section{Determination of Total RNA}

$75 \mu \mathrm{L}$ of supernatant was used for analysis of the total RNA. Total RNA was determined according to the method reported by Chomzynski and Sacchi, (1987). It was extracted from the supernatants of bee samples in three steps (extraction, precipitation by washing and redissolution), washed with ethanol and finally distilled twice. After these steps, total RNA was measured spectrophotometrically at $280 \mathrm{~nm}$ wavelength. This process was repeated 10 times for each bee race.

\section{Determination of Malondialdehyde (MDA) Level}

$1 \mathrm{~mL}$ of supernatant was used for analysis of MDA levels. MDA levels were determined according to the method reported by Beuge and Aust (1978). Serum samples were first treated with trichloroacetic acid (TCA) (1 mL 40\% TCA) and then thiobarbituric acid (TBA) (2 mL 67\% TBA) for protein precipitation. The mixture was heated in a boiling water bath for 10 minutes. The chromogen obtained was centrifuged and the color intensity formed in the supernatant was measured colorimetrically at $530 \mathrm{~nm}$. This process was repeated 10 times for each race.

\section{Determination of Catalase (CAT) Activity}

$20 \mu \mathrm{L}$ of supernatant was used for the analysis of catalase (CAT) activity. CAT activity in supernatants was measured by $\mathrm{H}_{2} \mathrm{O}_{2}$ Assay at $240 \mathrm{~nm}$ according to the method reported by Aebi (1984). Measurements were calculated as $\mathrm{kU} / \mathrm{g}$ protein. This process was repeated 10 times for each bee race.

\section{Statistical Analysis}

After the laboratory analyzes, the SPSS package program was used to obtain descriptive statistics for each of the biochemical characteristics of bee races and to compare the means of the characteristics (SPSS, 2008). Before the analysis of variance, firstly the normality of the data was tested with the Shapiro-Wilk test in all the characteristics examined, and then the differences among the means of the examined characteristics of the bee races were analyzed using one-way analysis of variance (ANOVA). Lastly, Duncan multiple comparison test was used to compare the mean of groups/races whose variance analysis results were statistically significant $(\mathrm{P}<0.05)$. Beside, all the results obtained from statistical analysis are also shown in tables and figures.

\section{Results and Discussion}

Descriptive statistics (Table 1) and normality test results of the examined biochemical characteristics of bee races are given below (Table 2 ).

From the values in Table 1, it is seen that the lowest variation in the biochemical characteristics of bee races is generally in total RNA, and the highest variability is in CAT enzyme activity (only at the level of MDA in Anatolian bee race). 
When the Shapiro-Wilk normality test results in Table 2 are examined; it is observed that there are normal distribution $(\mathrm{P}>0.05)$ in all of the biochemical characteristics of the bee races. For this reason, one-way analysis of variance method was used to compare the mean of the examined characteristics of the bee races. Variance analysis results are given below (Table 3 ).

When the variance analysis results in Table 3 are evaluated, it is seen that there are statistically significant differences $(\mathrm{P}<0.001$ for total protein, total RNA and MDA level, $\mathrm{P}<0.05$ for CAT activity) among bee races/groups in terms of the means of all biochemical characteristics examined.

The results of Duncan multiple comparison test (Table 4) and the bar graphs (Figure 1-4; with error bars at $95 \%$ confidence interval) of the means of biochemical characteristics to be found statistically significant among bee races/groups as a result of variance analysis are given below.
When the multiple comparison test results given in Table 4 and the graphics given in Figure 1-4 are evaluated, it is seen that Anatolian and Caucasian bee races have higher values than Muğla and Italian bee races in terms of total protein; Anatolian and Caucasian bee races have higher values than Muğla bee race and Muğla bee race has also higher values than Italian bee race in terms of total RNA; Anatolian and Caucasian bee races have higher values than Italian bee race, while Muğla bee race shows values between these two races in terms of CAT activity; Italian bee race shows higher values than the Caucasian bee race, the Caucasian bee race than the Anatolian bee race, and the Muğla bee race has value between the Italian and Caucasian bee races in terms of MDA levels. From these results, it can be said that Anatolian and Caucasian bee races can be more resistant to stressful environmental conditions than Italian and Muğla bee races in central Anatolia conditions.

Table 1. Descriptive statistics for the examined biochemical charecteristics of bee races $(n=10)$

\begin{tabular}{|c|c|c|c|c|c|}
\hline \multicolumn{2}{|c|}{ Charecteristics Races } & $\begin{array}{l}\text { Total Protein } \\
(\mathrm{g} / \mathrm{dL})\end{array}$ & $\begin{array}{c}\text { Total RNA } \\
(\mu \mathrm{g} / \mu \mathrm{L})\end{array}$ & $\begin{array}{c}\text { CAT } \\
(\mathrm{kU} / \mathrm{g} \mathrm{P})\end{array}$ & $\begin{array}{c}\text { MDA } \\
(\mathrm{mmol} / \mathrm{mg})\end{array}$ \\
\hline \multirow{5}{*}{ Italian } & Mean & 18.39 & 11.46 & 4.59 & 0.52 \\
\hline & Minimum & 16.78 & 11.23 & 3.83 & 0.47 \\
\hline & Maximum & 20.53 & 11.88 & 5.21 & 0.58 \\
\hline & $\mathrm{SD}$ & 1.28 & 0.18 & 0.46 & 0.04 \\
\hline & $\mathrm{CV}(\%)$ & 6.96 & 1.57 & 10.02 & 7.69 \\
\hline \multirow{5}{*}{ Muğla } & Mean & 18.56 & 11.87 & 4.88 & 0.50 \\
\hline & Minimum & 17.09 & 11.62 & 4.33 & 0.46 \\
\hline & Maximum & 20.38 & 12.16 & 5.73 & 0.56 \\
\hline & SD & 1.24 & 0.20 & 0.48 & 0.04 \\
\hline & $\mathrm{CV}(\%)$ & 6.68 & 1.68 & 9.84 & 8.00 \\
\hline \multirow{5}{*}{ Caucasian } & Mean & 20.71 & 12.10 & 5.12 & 0.48 \\
\hline & Minimum & 19.46 & 11.76 & 4.26 & 0.44 \\
\hline & Maximum & 21.57 & 12.54 & 6.32 & 0.50 \\
\hline & $\mathrm{SD}$ & 0.63 & 0.26 & 0.67 & 0.02 \\
\hline & $\mathrm{CV}(\%)$ & 3.04 & 2.15 & 13.09 & 4.17 \\
\hline \multirow{5}{*}{ Anatolian } & Mean & 20.95 & 12.27 & 5.25 & 0.43 \\
\hline & Minimum & 17.37 & 11.80 & 4.30 & 0.35 \\
\hline & Maximum & 24.95 & 12.61 & 6.21 & 0.58 \\
\hline & $\mathrm{SD}$ & 2.15 & 0.26 & 0.53 & 0.05 \\
\hline & $\mathrm{CV}(\%)$ & 10.26 & 2.12 & 10.10 & 11.63 \\
\hline
\end{tabular}

SD: Standard deviation, $\mathrm{CV}$ : Coefficient of variance

Table 2. Shapiro-Wilk normality test results for the biochemical charecteristics of bee races $(\mathrm{n}=10)$

\begin{tabular}{l|lcc}
\hline Charecteristics & \multicolumn{1}{c}{ Races } & Statistic & P \\
\hline \multirow{4}{*}{ Total Protein $(\mathrm{g} / \mathrm{dL})$} & Italian & 0.907 & 0.259 \\
& Muğla & 0.894 & 0.190 \\
& Caucasian & 0.948 & 0.648 \\
& Anatolian & 0.976 & 0.101 \\
\hline \multirow{5}{*}{ Total RNA $(\mu \mathrm{g} / \mu \mathrm{L})$} & Italian & 0.870 & 0.217 \\
& Muğla & 0.900 & 0.406 \\
& Caucasian & 0.926 & 0.428 \\
\hline & Anatolian & 0.928 & 0.623 \\
CAT $(\mathrm{kU} / \mathrm{g} \mathrm{P})$ & Italian & 0.946 & 0.381 \\
& Muğla & 0.923 & 0.604 \\
& Caucasian & 0.944 & 0.978 \\
\hline \multirow{5}{*}{ MDA $(\mathrm{mmol} / \mathrm{mg})$} & Anatolian & 0.983 & 0.790 \\
& Italian & 0.960 & 0.092 \\
& Muğla & 0.867 & 0.683 \\
\hline
\end{tabular}


Table 3. Variance analysis results for the biochemical charecteristics of bee races

\begin{tabular}{|c|c|c|c|c|c|c|}
\hline \multicolumn{2}{|c|}{ Charecteristics } & SS & $\mathrm{df}$ & MS & $\mathrm{F}$ & $\mathrm{P}$ \\
\hline \multirow{3}{*}{ Total Protein $(\mathrm{g} / \mathrm{dL})$} & Between Groups & 55.978 & 3 & 18.659 & 9.133 & 0.000 \\
\hline & Within Groups & 73.546 & 36 & 2.043 & & \\
\hline & Total & 129.524 & 39 & & & \\
\hline \multirow{3}{*}{ Total RNA $(\mu \mathrm{g} / \mu \mathrm{L})$} & Between Groups & 3.698 & 3 & 1.233 & 23.752 & 0.000 \\
\hline & Within Groups & 1.868 & 36 & 0.052 & & \\
\hline & Total & 5.567 & 39 & & & \\
\hline \multirow{3}{*}{ CAT (kU/g P) } & Between Groups & 2.553 & 3 & 0.851 & 2.914 & 0.047 \\
\hline & Within Groups & 10.514 & 36 & 0.292 & & \\
\hline & Total & 13.067 & 39 & & & \\
\hline \multirow{3}{*}{ MDA (mmol/mg) } & Between Groups & 0.049 & 3 & 0.016 & 12.147 & 0.000 \\
\hline & Within Groups & 0.048 & 36 & 0.001 & & \\
\hline & Total & 0.097 & 39 & & & \\
\hline
\end{tabular}

SS: Sum of square, df: degrees of freedom, MS: Mean square, F: F statistics, P: Probability

Table 4. The means of biochemical charecteristics of bee races $( \pm \mathrm{SD})$ and multiple comparison test results

\begin{tabular}{l|ccccc}
\hline $\begin{array}{c}\text { Charecteristics } \\
\text { Races }\end{array}$ & $\mathrm{n}$ & $\begin{array}{c}\text { Total Protein } \\
(\mathrm{g} / \mathrm{dL})\end{array}$ & $\begin{array}{c}\text { Total RNA } \\
(\mu \mathrm{g} / \mu \mathrm{L})\end{array}$ & $\begin{array}{c}\text { CAT } \\
(\mathrm{kU} / \mathrm{g} \mathrm{P})\end{array}$ & $\begin{array}{c}\text { MDA } \\
(\mathrm{mmol} / \mathrm{mg})\end{array}$ \\
\hline Italian & 10 & $18.39 \pm 1.28^{\mathrm{b}}$ & $11.46 \pm 0.18^{\mathrm{c}}$ & $4.59 \pm 0.46^{\mathrm{b}}$ & $0.52 \pm 0.04^{\mathrm{a}}$ \\
Muğla & 10 & $18.56 \pm 1.24^{\mathrm{b}}$ & $11.87 \pm 0.20^{\mathrm{b}}$ & $4.88 \pm 0.48^{\mathrm{ab}}$ & $0.50 \pm 0.04^{\mathrm{ab}}$ \\
Caucasian & 10 & $20.71 \pm 0.63^{\mathrm{a}}$ & $12.10 \pm 0.26^{\mathrm{a}}$ & $5.12 \pm 0.67^{\mathrm{a}}$ & $0.48 \pm 0.02^{\mathrm{b}}$ \\
Anatolian & 10 & $20.95 \pm 2.15^{\mathrm{a}}$ & $12.27 \pm 0.26^{\mathrm{a}}$ & $5.25 \pm 0.53^{\mathrm{a}}$ & $0.43 \pm 0.05^{\mathrm{c}}$ \\
\hline
\end{tabular}

Different letters in the same column indicate that there is a statistically significant difference between the means (Duncan multiple comparison test, $\mathrm{P}<0.05)$.

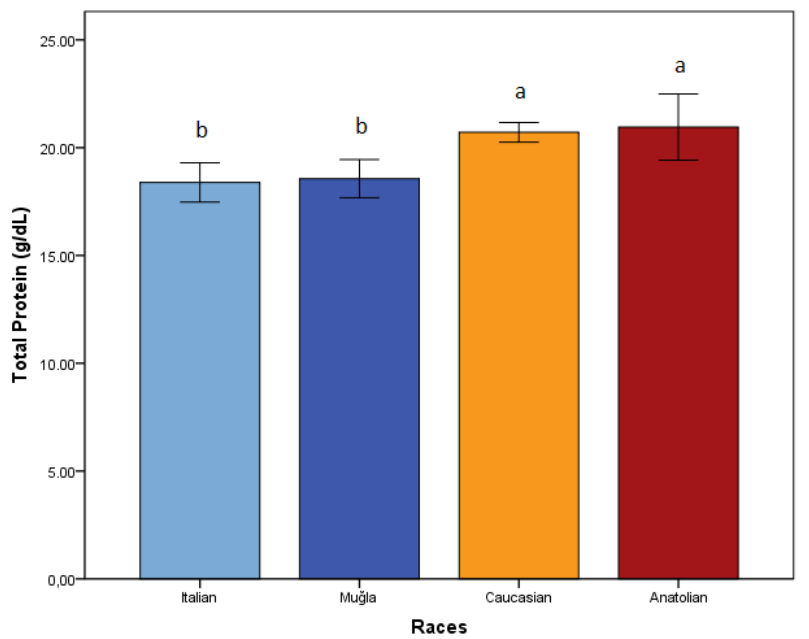

Figure 1. Total protein $(\mathrm{g} / \mathrm{dL})$ of bee races $(95 \%$ Confidence Interval)

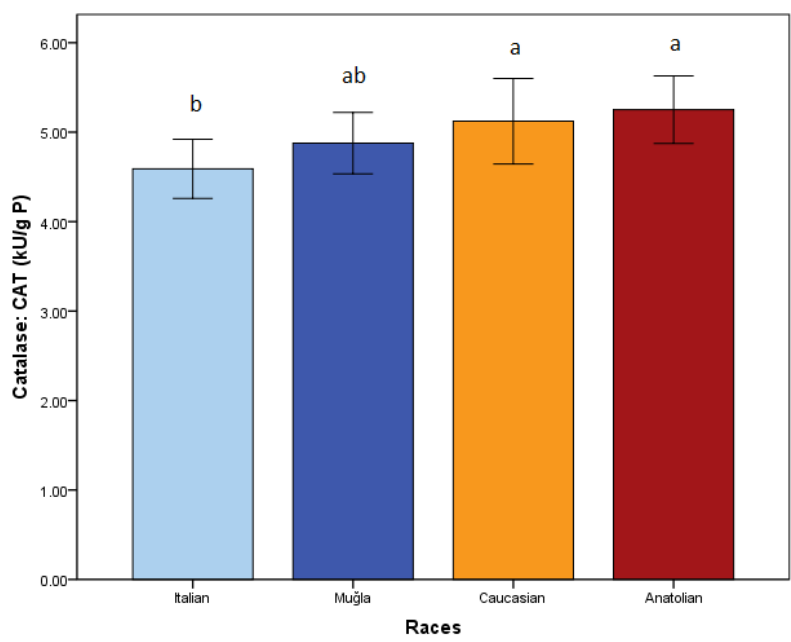

Figure 3. CAT (kU/g P) activities of bee races $(95 \%$ Confidence Interval)

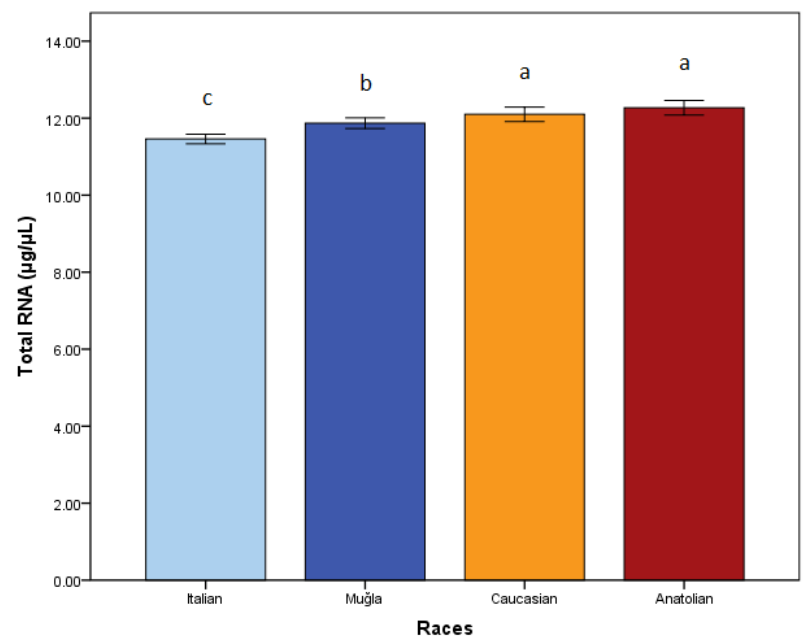

Figure 2. Total RNA $(\mu \mathrm{g} / \mu \mathrm{L})$ of bee races $(95 \%$ Confidence Interval)

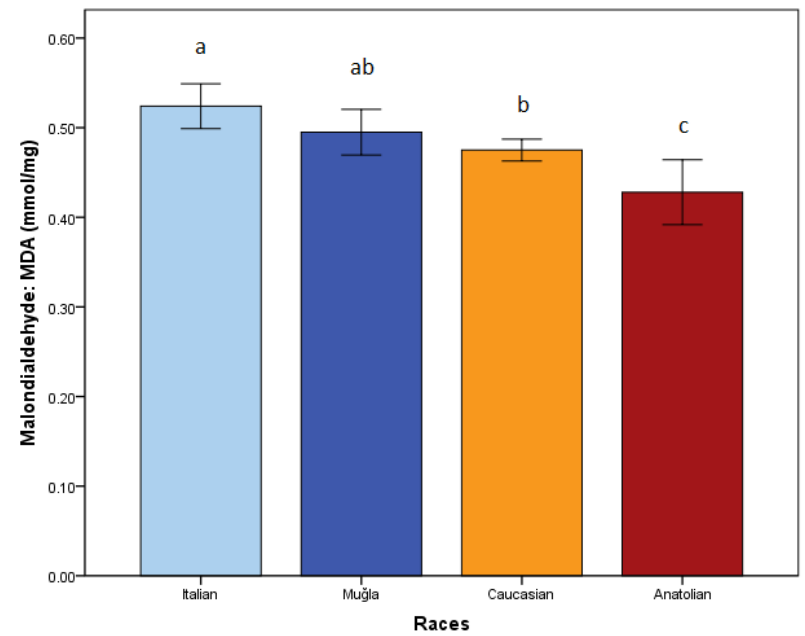

Figure 4. MDA (mmol/mg) levels of bee races $(95 \%$ Confidence Interval) 
Table 5. Pearson correlations between biochemical characteristics of bee races $(n=40)$

\begin{tabular}{l|ccc}
\hline \multicolumn{1}{c|}{ Charecteristics } & Total RNA & CAT & MDA \\
\hline Total Protein & $0.522^{* *}$ & $0.350^{*}$ & -0.231 \\
Total RNA & 1.000 & $0.414^{* *}$ & $-0.563^{* *}$ \\
CAT & & 1.000 & -0.201 \\
MDA & & & 1.000 \\
\hline
\end{tabular}

*: $\mathrm{P}<0.05 ;$ **: $\mathrm{P}<0.01$ (two-tailed hypothesis test)
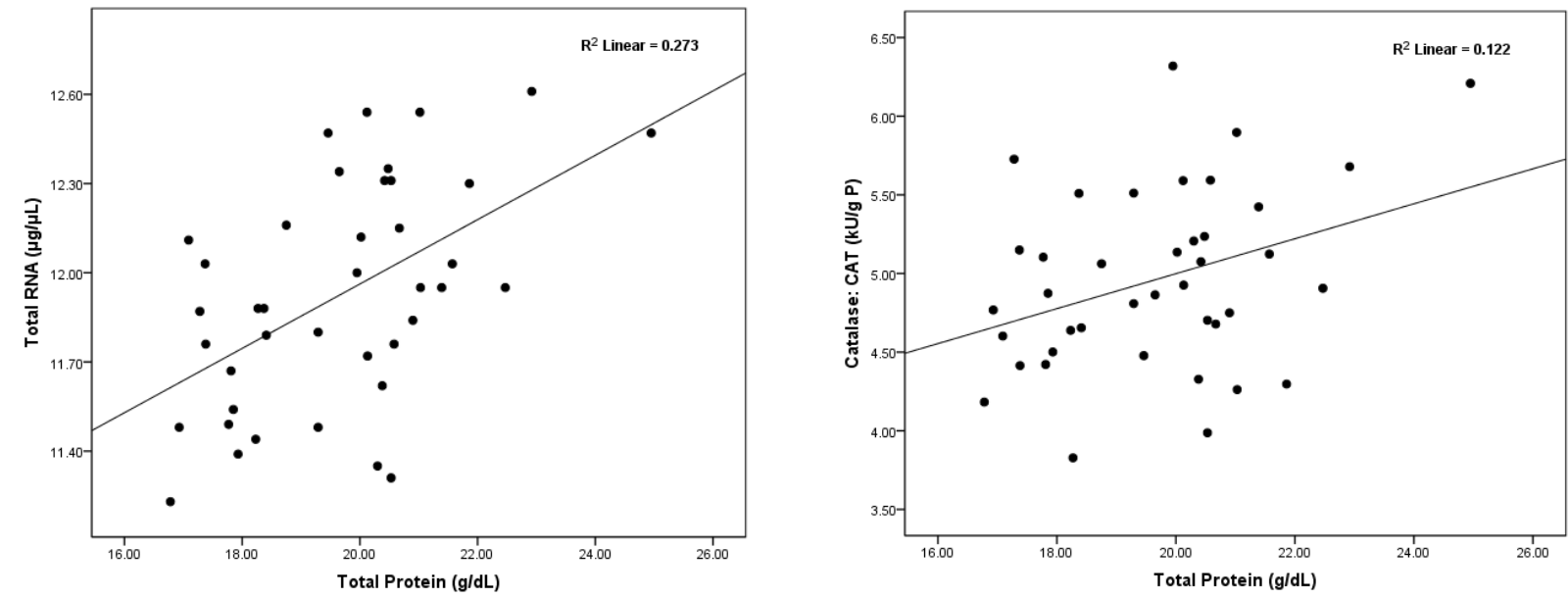

Figure 5. Linear relationship between total protein and total Figure 6. Linear relationship between total protein and CAT RNA activities

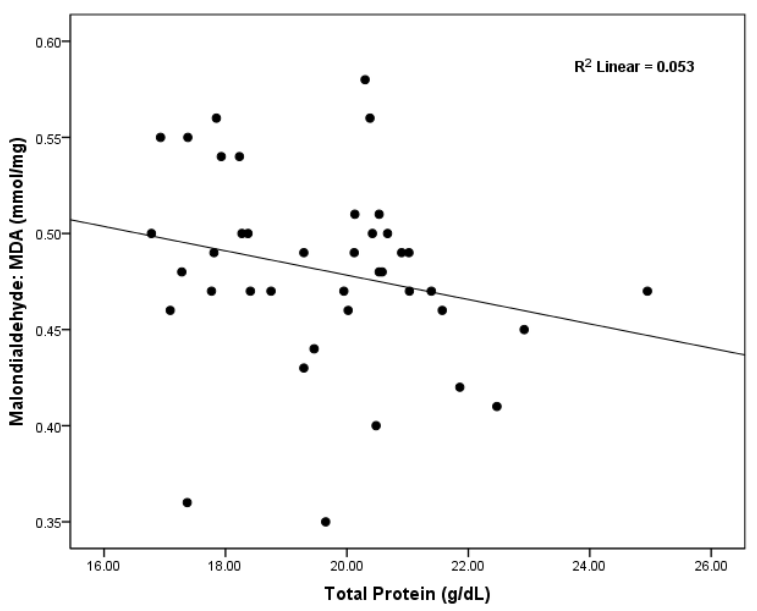

Figure 7. Linear relationship between total protein and MDA levels

In a study conducted in the province of Niğde by Ünalan and Akyol (2017), it was reported that the highest life expectancy was in the Niğde bee ecotype and the lowest life expectancy was in the Italian bee race, and as a result of the life analysis, the cumulative survival rates of Niğde ecotype, Caucasian, Muğla and Italian bee races reached to $0 \%$ in the $61 \mathrm{st}, 60 \mathrm{th}, 60 \mathrm{th}$ and 53rd days, respectively.

As summarized under the title of "Introduction" of the study, many studies have been conducted so far in order to determine or compare various physiological, morphological and yield characteristics of the honey bee races examined in this study. However, the number of studies conducted to determine the biochemical characteristics of these races is very few. Akyol et al. (2015) studied the total protein, total RNA and catalase (CAT) activities in Italian hybrid worker bees of different ages $(4,9,15,20$ and 24 old days). Total protein, total RNA

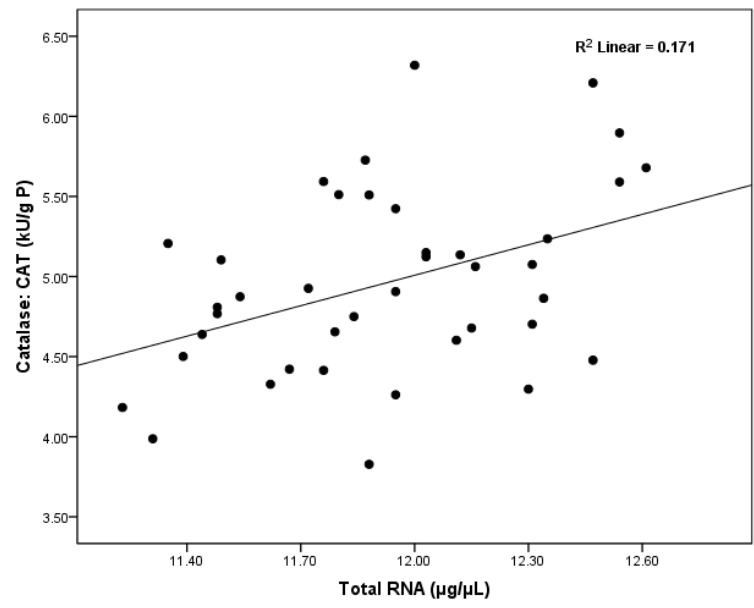

Figure 8. Linear relationship between total RNA and CAT activities

and catalase (CAT) activities of 24 old days worker bees reported by the authors as $18.73 \pm 0.93 \mathrm{~g} / \mathrm{dL}, 11.37 \pm 0.07$ $\mu \mathrm{g} / \mu \mathrm{L}$ and $4.47 \pm 0.48 \mathrm{kU} / \mathrm{g} \mathrm{P}$, respectively. They reported also that total protein and total RNA decreased statistically significantly with the increase of bee age, and CAT activity increased slightly with increasing age but this increase was not statistically significant. In the study, the results of the same biochemical characteristics of the Italian bee race were similiar the results informed by Akyol et al. (2015). In the study, the MDA level of $0.52 \mathrm{mmol} / \mathrm{mg}$ was found for Italian worker bees higher than the result informed by Chengcheng et al. (2012) as $0.46 \mathrm{mmol} / \mathrm{mg}$ for the control group for Italian adult worker bees on diets with different protein content.

Pearson's correlation coefficients (Table 5) and scatter plots (Figure 5-9) showing the general relationships between the biochemical charecteristics studied are given below. 


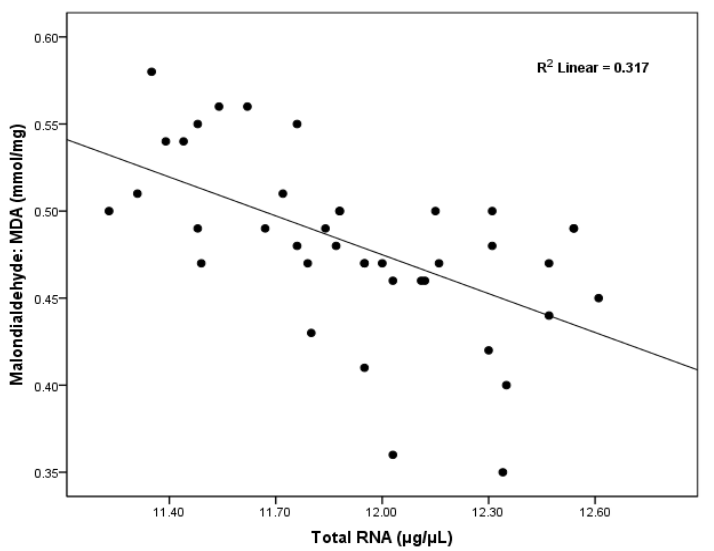

Figure 9. Linear relationship between total RNA and MDA levels

When the Pearson correlation coefficients in Table 5 and the scatter plots given in Figure 5-10 are examined, it is observed that there is a positive and statistically significant relationship between total protein and both total RNA and CAT enzyme activity, and there is a negative correlation between total protein and MDA levels but statistically insignificant. While there is a positive and significant relationship between total RNA and CAT enzyme activity, it is seen that there is a significant negative relationship between total RNA and MDA levels. It is seen that the relationship between CAT enzyme activity and MDA levels is negative, but this relationship is not statistically significant.

\section{Conclusion}

In this study, the fact that some biochemical characteristics of Italian, Caucasian, Muğla and Anatolian honey bee races, which are also widely honey bee races by beekeepers in our country, will be revealed, will contribute to the future scientific literature for similar purposes; Considering that malondialdehyde (MDA) levels, which is an indicator of the peroxidation of membrane lipids, and catalase (CAT) activities, one of the indicators of the antioxidant defense system, and the total protein include various proteins such as antioxidants and enzymes; among the statistical analysis results of the biochemical characteristics of the examined bee races; the resistance of Anatolian and Caucasian bee races to various negative environmental factors (climate, flora, pesticide etc.) it may be better than their races. In addition, it was concluded that these characteristics can be used in the characterization of bee races due to the significant differences between the bee races examined in terms of total RNA.

In addition, this research subject is evaluated in terms of bee breeding; in the future, it would be beneficial to investigate these or similar biochemical characteristics of the bee races in question, together with other yield (especially honey yield, etc.) and performance characteristics.

\section{Acknowledgement}

This study was supported by the Scientific Research Projects Coordination Unit of Niğde Ömer Halisdemir University within the scope of the project numbered FEB 2015/26 BAGEP.

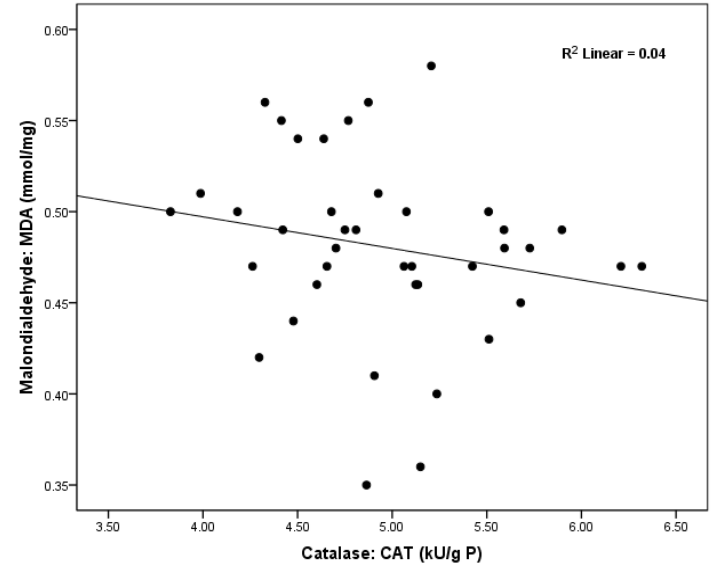

Figure 10. Linear relationship between CAT activity and MDA levels

\section{References}

Adl MBF, Gençer HV, Firatli Ç, Bahreini R. 2007. Morphometric characterization of Iranian (Apis mellifera meda), and Caucasian (Apis mellifera caucasica) honey bee populations. Journal of Apicultural Research, 46(4): 225-231.

Aebi H. 1984. Catalase in vitro. Methods in Enzymology, 105: 121-126.

Akyol E, Özkök D, Öztürk C, Bayram A. 2005. Bazı saf ve melez balarısı (Apis mellifera L.) kolonilerinin oğul eğilimi, yaşama gücü, kışlama yeteneği ve petek işleme etkinliklerinin belirlenmesi üzerine bir araştırma. Uludağ Arıcılık Dergisi, 5(4): $162-166$

Akyol E, Şahinler N, Özkök D. 2006. Honeybee (Apis mellifera) races, ecotypes and their general characteristics in Turkey. Journal of Animal and Veterinary Advances, 5(9): 771-774.

Akyol E, Selamoğlu Z, Gülhan MF. 2015. Determination of some biochemical parameters of worker honeybees (Apis mellifera L.) belonging to different age groups. Turkish Journal of Zoology, 39: 995-997.

Beuge JA, Aust SD. 1978. Microsomal lipid peroxidation. Methods in Enzymology, 52: 302-310.

Bouga M, Alaux C, Bienkowska M, Büchler R, Carreck NL, Cauia E, Chlebo R, Dahle B, Dall'Olio R, De la Rua P, Gregorc A, Ivanova E, Kence A, Kence M, Kezic N, Kiprijanovska H, Kozmus P, Kryger P, Le Conte Y, Lodesani M, Murilhas AM, Siceanu A, Soland G, Uzunov A, Wilde J. 2011. A review of methods for discrimination of honey bee populations as applied to European beekeeping. Journal of Apicultural Research, 50(1): 51-84.

Chengcheng L, Baohua X, Yuxi W, Qianqian F, Weiren Y. 2012. Effects of dietary crude protein levels on development, antioxidant status, and total midgut protease activity of honey bee (Apis mellifera ligustica). Apidologie, 43: 576-586.

Chomzynski P, Sacchi N. 1987. Single-step method of RNA isolation by acid guanidinium thiocyanate-phenol-chloroform extraction. Analytical Biochemistry, 162(1): 156-159.

Genç F, Dülger C, Dodoloğlu A, Kutluca S. 1999. Kafkas, Orta Anadolu ve Erzurum balarisı (Apis mellifera L.) genotiplerinin Erzurum koşullarındaki bazı fizyolojik özelliklerinin karşılaştırılması. Turkish Journal of Veterinary and Animal Science, 23: 645-650.

Güler A. 1999. Türkiye'nin bazı bal arısı (Apis mellifera L.) genotiplerinde verimi etkileyen morfolojik ve fizyolojik karakterler üzerine araștırmalar. Turkish Journal of Veterinary and Animal Science, 23: 393-393.

Güler A, Kaftanoğlu O. 1999. Türkiye'deki önemli balarısı (Apis mellifera L.) 1rk ve ekotiplerinin göçer arıcılık koşullarında performanslarının karşılaştırılması. Turkish Journal of Veterinary and Animal Science, 23: 577-581. 
Güler A. 2006. Bal Arısı (Apis mellifera). Ondokuz Mayıs Üniversitesi Ziraat Fakültesi Ders Kitab1, No: 55, Samsun.

Güler A. 2010. A morphometrics model for determining the effect of commercial queen bee usage on the native honeybee (Apis mellifera L.) population in Turkish province. Apidologie, 41: 622-635.

Güler A, Bıyık S, Güler M. 2011. Batı Karadeniz bölgesi balarısı (Apis mellifera L.) populasyonunun morfolojik özellikleri. 7. Ulusal Zootekni Bilim Kongresi, 14-16 Eylül 2011, Adana.

Kandemir I, Kence A. 1995. Allozyme variability in a Central Anatolian honeybee (Apis mellifera L.) population. Apidologie, 26: 503-510.

Kandemir I, Kence M, Kence A. 2000. Genetic and morphometric variation in honeybee (Apis mellifera L.) populations of Turkey. Apidologie, 31, 343-356.

Kekeçoğlu M. 2009. Honey bee biodiversity in Western Black Sea and evidence for a new honey bee ecotype in Yı̆g 1 lca province. Research Journal of Biology Science, 2(1): 73-78.

Kekeçoğlu M, Soysal Mİ. 2010. Genetic diversity of bee ecotypes in Turkey and evidence for geographical differences. Romanian Biotechnological Letters, 15(5): 5646-5653.

Lowry OH, Rosebrough NJ, Farr AL, Randall RJ. 1951. Protein measurement with the Folin phenol reagent. Journal of Biological Chemistry, 193(1): 265-275.

Palmer MN, Smith DR, Kaftanoglu O. 2000. Turkish honeybees: Genetic variation and evidence for a fourth lineage of Apis mellifera mtDNA. Journal of Heredity, 91: 42-46.
Ruttner F. 1988. Biogeography and Taxonomy of Honeybees. Springer, Verlag, Berlin, 1988.

Sheppard WS, Arias MC, Grech A, Meixner MD. 1997. Apis mellifera ruttneri, a new honey bee subspecies from Malta. Apidologie, 28: 287-293.

Sheppard WS, Meixner MD. 2003. Apis mellifera pomonella, a new honey bee subspecies from central Asia. Apidologie, 34: 367-375.

Silici S, Özkök D. 2009. Bal Arısı Biyolojisi ve Yetiştiriciliği. Eflatun Yayınevi, Ankara, 2009.

Smart LE, Stevenson JH. 1982. Laboratuary estimation of toxicity of pyrethroid insecticides to honey bees: Relevance to hazard in the field. Bee World, 63(4): 150-152.

Smith DR, Slaymaker A, Palmer M, Kaftanoglu O. 1997. Turkish honey bees belong to the east Mediterranean mitochondrial lineage. Apidologie, 28: 269-274.

SPSS, 2018. SPSS for Windows Ver. 24.0, SPSS Inc., Chicago, Illinois, USA.

Strange JP, Garnery L, Sheppard WS. 2008. Morphological and molecular characterization of the landes honey bee (Apis mellifera L.) ecotype for genetic conservation. Journal of Insect Conservation, 12: 527-537.

Ünalan A, Akyol E. 2017. Determination of fifespan of different honeybee (Apis Mellifera L.) genotypes (Nigde ecotype, Caucasian, Mugla and Italian) in Nigde province condition by survival analysis. 45th Apimondia International Apicultural Congress, September 29 - October 4, İstanbul, Turkey, 2017. 